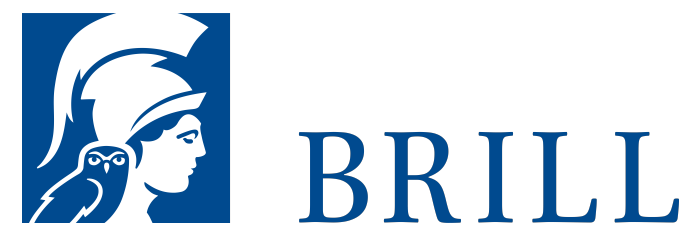

\title{
Über das Vorgestern ins Übermorgen
}

Neoprimitivismus in Wort- und Bildkunst der russischen

Moderne

Authors: Aage Ansgar Hansen-Löve and Aage A. Hansen-Löve

Der russische Neoprimitivismus im engeren Sinne war Anfang der 1oer Jahre des 20. Jahrhunderts ein zentrales Stück der russischen Bildkunst an der Schwelle zwischen Symbolismus bzw. Jugendstil und Avantgarde, zwischen Neoimpressionismus, Futurismus und Suprematismus. Hauptvertreter dieser vitalen Strömung waren Klassiker der russischen Moderne: Michail Larionov, Natalija Goncarova, Kasimir Malevic, Vasili Kandinski u.v.a. Sie verbanden die in jener Periode nach Russland importierten westlichen Primitivismen eines Picasso oder Braque mit der so reichen eigenen Tradition einer noch voll lebendigen Exotik der eigenen Folklore, des Schamanismus und der eben erst als Kunst entdeckten Ikonen- und Freskenmalerei des Mittelalters. Erstmals werden die intermediale Beziehung der neoprimitivistischen Bildkunst mit analogen Tendenzen in der Poesie der Symbolisten und Futuristen sowie die primitivistischen Tendenzen in der frühen Sowjetprosa untersucht.

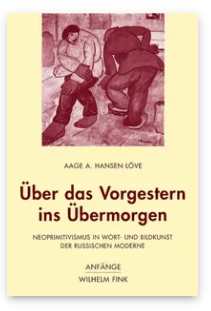

Pages: 506

Seiten, $13 \mathrm{~s} / \mathrm{w}$ und 25 farb. Abb.

Language:

German

Subjects: Slavic, Literature and Cultural Studies

Publisher: Brill | Fink

Series: Anfänge

E-Book (PDF)

Released online: 24 Sep 2019 ISBN: 978-38467-5947-9 List price

Paperback

Publication date: 10 Jun 2016

ISBN: 978-3-

7705-5947-3

List price 
For more information see brill.com

Order information: Order online at brill.com +44330 333 0049 | customerservices@brill.com Submission information: brill.com/authors

Titles published by Brill | Fink, Brill | mentis or Brill | Schöningh: +49(o)715413279216| brill@brocom.de 